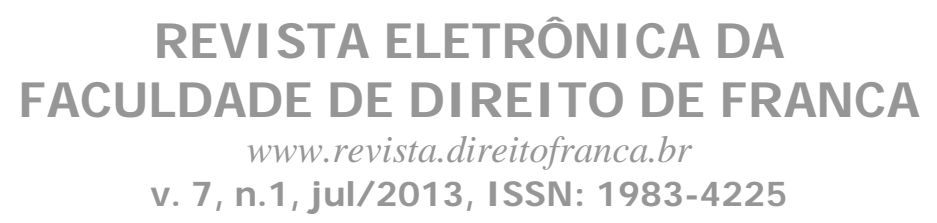

\title{
DIREITO PENAL, CONTRAVENÇÕES PENAIS E DIREITO ADMINISTRATIVO SANCIONADOR
}

\section{Guilherme Gouvêa De Figueiredo}

http://buscatextual.cnpq.br/buscatextual/visualizacv.do?id=K4250128P6

\begin{abstract}
Resumo: A distinção entre o ilícito penal e o ilícito administrativo está longe de ser algo carente de efeito prático-jurídico. Em tempos em que o Direito Penal se expande de forma aleatória, cabe ao direito administrativo sancionador um lugar fundamental, como instrumento legislativo atrelado ao paradigma da intervenção mínima, nomeadamente na sua vertente descriminalizadora. É, pois, tempo de repensar a função sancionatória do direito administrativo. Visto e revisto, o direito administrativo sancionador aponta de forma absoluta para a incoerência político-criminal das vetustas contravenções penais e oferece um instrumento de apoio para o Direito Penal secundário.
\end{abstract}

Palavras-Chave: Direito Penal, Contravenções Penais, Direito Penal Secundário, Descriminalização, Bens jurídico-penais, Política Criminal

\section{Criminal Law, Criminal Contravention and Sanctioner Administrative Law}

Abstract: The distinction between the criminal offense and administrative offense is far from being something lacking in practical and legal effect. In times when the Criminal Law expands randomly, the administrative sanctioner law assumes a fundamental place, as a legislative instrument linked to the paradigm of minimal intervention, particularly in its decriminalizer side. It is, therefore, time to rethink the sanctioning role of administrative law. Viewed and reviewed, the sanctioner administrative law points out absolutely to the politicalcriminal inconsistency of old criminal contravention and offers a support tool for the secondary Criminal Law.

Keywords: Criminal Law, Criminal Offences, secondary Criminal Law, Decriminalization, criminal law protected interests, Criminal Policy.

\section{INTRODUÇÃO}

1.1. O empenho em retirar do campo do "penal” todas as condutas de questionável ofensividade a valores indispensáveis ao livre desenvolvimento do homem e, ao mesmo tempo, restringir a ameaça e a concreta punição por meio de sanções penais aos casos de indiscutível necessidade não é coisa recente. Já na altura do chamado iluminismo penal, tempo em que desponta o nome de BECCARIA, surge a preocupação em humanizar as penas, 


\section{REVI STA ELETRÔNI CA DA \\ FACULDADE DE DI REITO DE FRANCA}

www.revista.direitofranca.br

v. 8, n.1, jul/ 2013, ISSN: 1983-4225

atribuí-las uma finalidade preventiva e não somente retributiva e restringir o conjunto de comportamentos dignos de tutela penal. ${ }^{1}$

Modernamente, depois dos dois grandes conflitos mundiais, renasce na Europa, especificamente na Alemanha, o interesse em depurar o direito penal, extirpando do seu horizonte todas aquelas condutas de questionável relevo jurídico-criminal. Assim, “no período entre o fim dos anos sessenta e início dos setenta, emergem no seio da doutrina alemã posições unidas por um intento semelhante: edificar um conceito 'material' de bem jurídico sobre a base de critérios verdadeiramente aptos a vincular as escolhas de criminalizar do legislador ordinário”2 ${ }^{2}$ O bem jurídico passa então a fazer parte do discurso jurídico-penal como um elemento fulcral e parte inarredável daquele empenho de eliminar do campo penal todas aquelas condutas de discutível relevo ético-jurídico. Digno de tutela penal, ou, segundo outra terminologia, merecedor de pena, será todo o comportamento que implique na ofensa ou exposição a perigo de bens jurídico-penais. Surge, por conseqüência, o movimento de descriminalização ${ }^{3}$, que tem como principais interlocutores o mesmo conceito de bem jurídico-penal e o princípio da subsidiariedade.

Desse impulso de restrição do âmbito do penalmente tutelável animou-se o paradigmático “Alternativ Entwurf eines StGB von 1966”4 . Projeto de código penal alemão, alternativo ao governamental, que propunha uma ampla reformulação do sistema e, quanto ao que nos interessa mais diretamente, a descriminalização daqueles comportamentos meramente contrários a uma certa concepção moral. Daí surgiu a exigência de reforma da parte especial, nomeadamente dos crimes sexuais e contra a religião, em consonância com a conhecida necessidade "de que as ações que não afetam os direitos de ninguém e que se desenrolam entre pessoas adultas em privado (homossexualidade simples, sodomia, rufianismo, etc.), não

\footnotetext{
1 Nas palavras de FARIA COSTA, "BECCARIA não só rejeita, sem rebuço ou hesitação, a invasão incondicional da lei penal, no âmbito da liberdade individual, mas, para além disso - e aqui reside uma especificidade de grande relevo-, considera ainda que o único pressuposto válido para admitir a compressão da liberdade só encontra arrimo quando a lei penal prossegue legítimas exigência da sociedade. Se, para a medida dos crimes (...) o critério fundamental da criminalização é o ‘dano causado à nação’ , não podem, legitimamente, aparecer como crimes condutas que não produzam tal resultado...” (Ler Beccaria hoje in BECCARIA, Cesare, Dos Delitos e das Penas, tradução: José de FARIA COSTA, Ed: Fundação Calouste Gulbenkian, Lisboa:1998, p. 10)

${ }^{2}$ FIANDACA, Giovanni. Il bene giuridico come problema teorico e come criterio di politica criminale in RIDPP., 1982., p. 45.

${ }^{3}$ Um panorama do movimento de descriminalização, tal como surgido na Alemanha, e a teoria do bem jurídico encontramos em ROXIN, Problemas fundamentais de Direito Penal, Ed: Vega, Lisboa: 1998, p. 59 e ss. Também: FIGUEIREDO DIAS, Direito Penal Português (as conseqüências jurídicas do crime), Ed: Notícias, Lisboa: 1993, p. 65 e ss.

${ }^{4}$ Sobre o Projeto, desenvolvidamente, cf. ROXIN. Problemas fundamentais, p. 53 e ss.
} 


\section{REVI STA ELETRÔNI CA DA FACULDADE DE DI REITO DE FRANCA}

www.revista.direitofranca.br

v. 8, n.1, jul/ 2013, ISSN: 1983-4225

cabem na esfera de atuação do legislador penal" ${ }^{5}$. Nas reformas penais que se seguiram, diretamente influenciadas pelo Projeto Alternativo, o legislador germânico interveio de forma particularmente contundente; “abrogando, por exemplo, com o $1^{\circ} S t R G$ de 1969, os delitos de adultério, de homossexualidade 'simples', isto é, entre maiores do sexo masculino (maschi maggiorenni) e sem abuso das relações de dependência, e também a prática da bestialidade. Sucessivamente, seguindo esta linha de princípio, move-se o $4^{\circ} \operatorname{StRG}$, de 23 de novembro de 1973, aludindo ao direito penal sexual (...)”6.

Do mesmo projeto descriminalizador abrolha, também antes entre os germânicos ${ }^{7}$, uma outra postura político-criminal que interessa sobremaneira ao tema que pretendemos tratar e que se sintetiza na idéia de que devem excluir-se do âmbito de proteção penal (devem ser descriminalizadas) as condutas que, não atentando contra um bem jurídico digno de punição e claramente individualizado, apenas contravenham disposições do EstadoAdministrador. Ainda mais: mesmo que lesionem ou exponham a perigo um bem jurídico, não se tem por legítima a sanção criminal quando for possível atingir a mesma finalidade com instrumentos menos danosos que os jurídico-criminais (necessidade de pena ou carência de tutela penal).

Ademais, é paralelamente a esse novo programa político-criminal que vem a lume, em tom renovado, a discussão em torno das contravenções e sua conversão em contraordenações. Em outras palavras, foi um dos sintomas do movimento de descriminalização a afirmação definitiva de uma nova categoria (não penal) de ilícito - o ilícito de mera ordenação social ou ilícito administrativo sancionador -, para onde deveriam ser remetidas todas as condutas de questionável relevo ético, com exceção das que deveriam ser extirpadas, pura e simplesmente, da ordem jurídica. Era, por outro lado e progressivamente, o fim daquela categoria (penal) à qual pertenciam a maioria dessas condutas - as contravenções.

De qualquer modo, importa deixar claro que todas essas transformações políticolegislativas descritas foram influenciadas pelas reivindicações de um certo setor doutrinário

\footnotetext{
${ }^{5}$ Cf. ROXIN. Problemas fundamentais, p. 60.

${ }^{6}$ Cf. PALAZZO, Francesco Carlo. Valores constitucionais e direito penal: um estudo Comparado. Porto Alegre: Sérgio Antônio Fabris, 1989., p. 90.

7 Em Portugal, o CP de 1982 é claro exemplo dessa vertente descriminalizadora e, conseqüentemente, da afirmação do princípio da tutela exclusiva de bens jurídico-penais como conquista irrenunciável da moderna política criminal. Elucidativo, nesse sentido, o preâmbulo do Código Penal Português vigente: "O Código assume-se deliberadamente como ordenamento jurídico-penal de uma sociedade aberta e de um Estado democraticamente legitimado. Optou conscientemente pela maximização das áreas de tolerância em relação a condutas ou a formas de vida que relevando de particulares mundividências morais e culturais não põem directamente em causa os bens jurídico-penais nem desencadeiam intoleráveis danos sociais”.
} 


\section{REVI STA ELETRÔNI CA DA FACULDADE DE DI REITO DE FRANCA \\ www.revista.direitofranca.br \\ v. 8, n.1, jul/ 2013, ISSN: 1983-4225}

mais consciente das benesses de um programa político-criminal auto-restritivo, apto a impor limites materiais à intervenção punitiva do Estado. A necessidade de sublinhar, mesmo que a traço largo, o legado desde movimento descriminalizador e suas mais notórias linhas de força nos salta aos olhos à medida que nos deparamos, contemporaneamente, com uma tendência de expansão do direito penal e flexibilização dos seus pressupostos básicos de imputação. E daí a conseqüente adoção de programas político-criminais que rompem com os postulados de restrição da intervenção penal atrás delineados.

1.2. O tempo presente se singulariza pela ruptura e pelo casuísmo. Ruptura e casuísmo que sugerem, atentos nós a um específico nódulo de preocupações, um esfumaçar dos limites entre o direito penal e o administrativo.

O direito penal contemporâneo tem como uma das suas mais instantes características ter vindo a se afirmar na tutela de "contextos" cada vez mais amplos, como proteção antecipada de condições para o desfrute dos bens jurídicos mais clássicos (como a vida ou o patrimônio $)^{8}$. Assiste-se, desse modo, uma “dissolução” do conceito de bem jurídico que, deixando de se circunscrever a interesses pessoais claramente referenciáveis, passa a abranger novas necessidades coletivas ou "unidades funcionais de valor" ${ }^{9}$. O que, na visão de BARATTA, acaba por redundar numa mudança de rumo e orientação tanto ao nível político criminal quanto dogmático ${ }^{10}$. Portanto, do ponto de vista prático, “os legisladores têm promulgado e promulgam numerosas novas leis penais e as respectivas rationes legis (..) são acedidas de modo imediato à condição de bens jurídicos protegíveis (já que estão protegidos)”"11. À noção de bem jurídico, antes alçada como ponto fulcral do discurso descriminalizante, passa-se a atribuir uma função criminalizante, na medida em que legitima a intervenção penal sempre que haja a efetiva proteção legal ${ }^{12}$.

Se antes o direito penal se servia do bem jurídico, como referente material a suportar o tipo e como base da ilicitude material, agora, orientado à proteção de “funções” cada vez mais amplas e de desenho cada vez menos apreensível, àquele conceito não se pode pedir muito.

\footnotetext{
${ }^{8}$ Cf. SILVA SÁNCHEZ. La expansión del Derecho penal. Aspectos de la política criminal de las sociedades postindustriales. Madrid: Civitas, 1999. p. 122.

9 A expressão é de RUDOLPHI, apud HASSEMER. Lineamentos de una teoría personal del bien jurídico, Doctrina Penal, año 12, n. 45 a 48, Buenos Aires, 1989, p. 279.

${ }^{10}$ Cf. BARATTA. Alessandro. Integración-prevención: una "nueva" fundamentación de la pena dentro de la teoría sistémica, Doctrina Penal, n² 29, 1985, p. 11.

${ }^{11}$ Cf. SILVA SÁNCHEZ. Expansion..., p. 122.

${ }^{12}$ Cf. HASSEMER. Teoria personal del bien jurídico..., p. 278.
} 


\section{REVI STA ELETRÔNI CA DA FACULDADE DE DI REITO DE FRANCA \\ www.revista.direitofranca.br \\ v. 8, n.1, jul/ 2013, ISSN: 1983-4225}

Percebe-se que, de um domínio que se concentrava em responder à lesão a bens individuais, transmuda-se (o direito penal) num outro que passa a intervir logo quando se exponha a perigo (abstrato) bens supra-individuais. Desse modo, para além de o bem jurídico que se tem por referência ser pouco preciso - o que dificulta ou impossibilita seu potencial crítico e fundamentador do tipo -, o legislador opta por técnicas de incriminação em que o elo entre tipo de ilícito e bem jurídico existe apenas como ratio legis não sujeita a constatação no momento de aplicar o tipo. Em outra palavras, não é possível (ou necessário) comprovar um resultado desvalioso - mesmo que seja um resultado de perigo - para o bem jurídico que se tem por meta proteger.

Administrativização do direito penal significa, portanto, a assunção de uma nova postura político-criminal por parte do legislador. À custa do abandono do conteúdo liberal do conceito de bem jurídico, e com todas as implicações dogmáticas que daí advém, diz-se que o direito penal se administrativizou: “essa orientação à proteção de contextos cada vez mais genéricos (no espaço e no tempo) do desfrute dos bens jurídicos clássicos, leva o direito penal a entrar em relação com fenômenos de dimensões estruturais, globais ou sistêmicas, nos quais as aportações individuais, são, pelo contrário, de 'baixa intensidade”,"13. Como o que se protege são contextos genéricos e de questionável potencialidade crítica, o direito penal é levado a responder, com seus instrumentos próprios de atuação, tão logo quando se contravenha os standards estabelecidos pela Administração. Rompendo com a tradição de se orientar à salvaguarda de bens jurídicos concretos e determinados e reagir a formas de lesão ou perigosidade também concretas e determináveis, o direito penal vê-se vocacionado, tal como o direito administrativo sancionador, a perseguir funções de ordenação de setores da atividade administrativa.

Ora, se é no direito penal secundário onde se percebem, com clareza e atualidade, manifestações desta administrativização do direito penal - atentemos para a recente inflação legislativa, a proliferação de bens jurídico nebulosos (v.g. o meio ambiente ${ }^{14}$, a ordem econômica, etc.), a flexibilização das regras de imputação, o recurso indiscriminado à figura típica do perigo abstrato, a extrema dependência administrativa dos tipos ${ }^{15}$ - , não seria, em

\footnotetext{
${ }^{13}$ Cf. SILVA SÁNCHEZ. Expansion, p. 122.

14 Cf. FIGUEIREDO, Guilherme Gouvêa de , CRIMES AMBIENTAIS À LUZ DO CONCEITO DE BEM JURÍDICO-PENAL (des)criminalização, redação típica e (in)ofensividade,IBCCRIM, São Paulo: 2008.

${ }^{15}$ Sobre o que se afirmou, desenvolvidamente, MENDOZA BUERGO, Blanca. El derecho penal en la sociedad del riesgo. Madrid: Civitas, 2001, passim.
} 


\section{REVI STA ELETRÔNI CA DA FACULDADE DE DI REITO DE FRANCA \\ www.revista.direitofranca.br \\ v. 8, n.1, jul/ 2013, ISSN: 1983-4225}

contrapartida, desarrazoado afirmar que o sistema jurídico-penal brasileiro guarda ainda um exemplo nada novo e particularmente expressivo de tudo isso: a Lei de Contravenções Penais.

De fato, no Brasil, ainda vigoram as Contravenções Penais (Decreto-Lei 3.688 de outubro de 1941) que, conforme veremos, exemplificam de forma peculiar a incongruência do nosso sistema punitivo e a falta de linearidade dos seus pressupostos de legitimação. A vigência da Lei de Contravenções Penais é, assim, um exemplo de um sistema penal casuísta, desapegado a preocupações científicas e desatento à exigência político-criminal por um direito penal mínimo e, ao mesmo tempo, eficaz. Na Lei de Contravenções Penais estão definidas infrações que, na sua quase totalidade, não são ofensivas a bens jurídico-penais. Estão, por outro lado, previstas outras condutas que, mesmo ofensivas a bens jurídicos, poderiam muito bem ser objeto de punição, de forma menos agressiva e mais eficaz, por outro ramo do direito: o direito administrativo sancionador.

Daí porque uma analise crítica da categoria das contravenções deve partir de duas linhas de abordagem: (a) a retomada do conceito material de crime e, consequentemente, da noção de bem jurídico-penal, como condutor de mandamentos de descriminalização e (b) a afirmação de um novo ramo do direito (o direito administrativo sancionador) como categoria apta a, em homenagem ao princípio da subsidiariedade, tutelar determinadas formas de ofensa a bens jurídicos pela imposição de sanções menos drásticas e mais eficientes que as jurídico-penais.

\section{CONTRAVENÇÕES PENAIS E O PRINCÍPIO DA OFENSA A BENS JURÍDICOS}

Como, pela superfície, já se explicitou, da assunção de um conceito de bem jurídico com força crítica e metapositiva advém o mandamento de descriminalização de todas aquelas condutas que não importam numa ofensa ou exposição a perigo de um bem jurídico.

A definição do bem jurídico protegido serve, pois, quando minimamente precisa, de duas formas, ambas de inegável relevo político-criminal e dogmático: (a) de lege lata, a noção do valor protegido opera como parâmetro ao juízo de imputação de uma conduta concreta à descrição abstrata contida no tipo; (b) de lege ferenda, como é sabido, o bem jurídico é o limite que deve o legislador obedecer para a legítima tipificação de crimes vocacionados para uma proteção penal apegada a padrões restritivos. Assim, o bem jurídico é um dos grandes suportes aos mandamentos de descriminalização porque, sendo certo o valor que legitima a 


\section{REVI STA ELETRÔNI CA DA FACULDADE DE DI REITO DE FRANCA \\ www.revista.direitofranca.br \\ v. 8, n.1, jul/ 2013, ISSN: 1983-4225}

intervenção punitiva do Estado, todos aqueles tipos legais de crime não construídos para a tutela deste mesmo valor devem ser descriminalizados. Nesta linha, surge o bem jurídico também como grande referencial para as técnicas de redação típica ${ }^{16}$. Assim, clarificado o que se tem como meta proteger, mais fácil será o labor de descrição da conduta típica: só serão criados tipos legais cujo preenchimento de fato importe numa ofensa ou perigo de ofensa ao bem jurídico que confere legitimidade ao tipo, afastando-se, assim, o recurso indiscriminado a ilícitos de "mera desobediência" e de perigo abstrato (na forma de perigo presumido), em que se pune o simples descumprimento de um dever ${ }^{17}$.

2.1. Mas, antes de tudo, é preciso antever se estamos diante de verdadeiros bens jurídicos coletivos ou, contrariamente, de formas de antecipação da tutela de bens jurídicos individuais $^{18}$. É o que se passa com o bem jurídico "paz pública”, que foi objeto de atenção pela lei de contravenções penais. De acordo com a doutrina majoritária seria a "paz pública” um bem jurídico coletivo, visando à proteção de um “estado de segurança jurídica geral” assim como a consciência ínsita nos cidadãos de estarem seus interesses legítimos protegidos pela ordem jurídica ${ }^{19}$. Mas a necessidade de assegurar, pelo direito penal, a confiança das pessoas, não basta para a configuração de um bem jurídico coletivo. Falta aqui um objeto concreto, como, por exemplo, a segurança no tráfego monetário e, portanto, a referida “confiança na eficácia protetora do ordenamento jurídico” não constitui um interesse digno de justificar a legitimidade da intervenção penal ${ }^{20}$. O correto seria identificar os concretos bens jurídicos individuais expostos a perigo.

Por ser assim, é imprescindível o trabalho de delimitação dos "verdadeiros bens jurídicos coletivos" na medida em que, se de fato forem valores atrelados a interesses supraindividuais, a sua concepção não implique em conceitos “desmaterializados”. Essa crise de legitimidade por que passa a noção de bem jurídico, a ponto de alguns doutrinadores

\footnotetext{
${ }^{16}$ Afirmando, no mesmo sentido que "il concetto di bene giuridico fornisce indicazioni per una giusta tecnica di tutela delle leggi penali”: HASSEMER, Winfried, Il bene giuridico nel rapporto di tensione tra constituzione $e$ diritto naturale, Dei Delitti e Delle Pene, n¹, 1984, p. 109.

${ }^{17}$ FIGUEIREDO, CRIMES AMBIENTAIS, p. 141 e ss.

${ }^{18}$ Cf. HEFENDEHL, Roland, El bien jurídico como eje material de la norma penal, in: HEFENDEHL, Roland, La teoria del bien juídico, Marcial Pons, Barcelona: 2007, p. 182 e ss.

${ }^{19}$ Desta forma, “uma perturbação (lesão) da paz pública existiria, segundo esta tese, quando um certo número, indeterminado, mas em todo caso grande, de grupos da população virem menosprezada sua confiança (...) na eficácia protetora do ordenamento jurídico”( HEFENDEHL, Idem, p. 186).

${ }^{20}$ FRISCH, Bien jurídico, derecho, estrutura del delito e imputación em el contexto de la legitimación de la pena estatal, in: HEFENDEHL, Roland, La teoria del bien juídico, Marcial Pons, Barcelona: 2007,, p. 313
} 


\section{REVI STA ELETRÔNI CA DA \\ FACULDADE DE DI REITO DE FRANCA}

www.revista.direitofranca.br

v. 8, n.1, jull/ 2013, ISSN: 1983-4225

afirmarem estar o conceito em seu "leito de morte” ${ }^{21}$, está certamente relacionada à perda de seu potencial crítico, nomeadamente em relação aos chamados “novos bens jurídicos”, surgidos com o Estado Social, próprios de um Direito Penal já há tempos fundamentado pelo pós-moderno conceito de "sociedade do risco"22.

Mas, se o problema da falência do conceito de bem jurídico é também algo muito contemporâneo e peculiar ao direito penal secundário, do mesmo déficit de legitimidade padecem as contravenções penais. Pela simples leitura da vigente Lei de Contravenções Penais (Decreto-Lei 3688/41), percebe-se que vários dos interesses ali definidos não são autênticos bens jurídicos coletivos.

Atentemos para os criticados bens jurídicos paz e fé publicas (Capítulos IV e V) e, de forma ainda mais emblemática, a "polícia de costumes” (Cap. VII). Os dois primeiros tem a sua legitimidade extremamente discutível por serem conceitos de extrema vaporosidade. Dificilmente se consegue concretizar a noção de paz ou fé publicas, de modo que não se logra precisar quando a conduta típica ofende ou expõe a perigo o bem jurídico. Por lógica decorrência, a técnica de tutela acaba por descrever uma ação ou omissão que prescindem um juízo de tipicidade material, bastando o preenchimento formal do ilícito-típico para que haja a imputação. O perigo (abstrato) que o comportamento típico oferece ao bem jurídico (coletivo) é mera presunção legal, de forma que a legitimidade da incriminação só se obtém a partir de uma ofensa virtual ou hipotética. Assim, por exemplo, a contravenção que pune a "associação secreta” (art. 40) ou a "provocação de tumulto” (art. 42). Da mesma forma, quanto à fé pública, a "recusa de moeda de curso legal” (art. 43) ou o "uso ilegítimo de uniforme ou distintivo" (art. 46).

Ainda mais discutível é a validade das contravenções que protegem a "polícia de costumes”. Ora, se a afirmação do conceito de bem jurídico com força metajurídica fora o instrumento principal de combate àquelas incriminações que tinham como fulcro a salvaguarda de um qualquer valor moral, conclui-se de pronto pela incoerência políticocriminal das contravenções definidas para tutelar o costume, ainda mais quando se nota que o

\footnotetext{
${ }^{21}$ Crítico desta idéia e defensor da manutenção do conceito, vinculado à categoria do merecimento de pena: SCHUNEMANN, Bernd, El principio de protección de bienes como punto de fuga de los límites constitucionales de los tipos penales y de su interpretación, in: HEFENDEHL, Roland, La teoria del bien juídico, Marcial Pons, Barcelona: 2007, p. 197. Sobre as alternativas concepções que negam o conceito de bem jurídico, em autores como HIRSCH, STRATENWERTH e JAKOBS e a defesa da manutenção do conceito, por todos: ROXIN, Claus, Es la protección de bienes jurídicos uma finalidad del derecho penal?, in: HEFENDEHL, Roland, La teoria del bien juídico, Marcial Pons, Barcelona: 2007, p. 445 e ss.

${ }^{22}$ Cf. BECK, Ulrick, Risk Society, passim. MENDOZA BUERGO, Blanca. El derecho penal en la sociedad del riesgo. Madrid: Civitas, 2001, passim.
} 


\section{REVI STA ELETRÔNI CA DA FACULDADE DE DI REITO DE FRANCA \\ www.revista.direitofranca.br \\ v. 8, n.1, jul/ 2013, ISSN: 1983-4225}

que o legislador define como contrário ao costume não o é (v.g. a contravenção que pune criminalmente o “jogo do bixo”, art. 58; a “embriaguez”, art. 62; “vadiagem”, art. 59). Nas palavras de FIGUEIREDO DIAS, “não é função do direito penal, nem primária, nem secundária tutelar a virtude ou a moral: quer se trate da moral estatalmente imposta, da moral dominante, ou da moral específica de um qualquer grupo social”23.

Em suma, são todas contravenções, a nosso ver, destituídas de um autêntico bem jurídico coletivo e, ao mesmo tempo, inofensivas a interesses individuais. Infrações que, porquanto indignas de tutela penal, devem ser descriminalizadas ou, quando muito, se dotadas de alguma carga ofensiva para a manutenção de funções de ordenação do EstadoAdministrador, transformadas em ilícitos administrativos.

2.2. Por outro lado, não se nega que há contravenções que tem como objeto material bens jurídicos dotados de dignidade penal. Assim, por exemplo, a "pessoa” ou o "patrimônio" (Capítulos I e II). Mas, o que aqui devemos ter em conta é se tais contravenções de fato afetam o interesse que tem por meta proteger ou se, contrariamente, são infrações inofensivas para o bem jurídico. Isto porque, faz parte das exigências constitucionais de proporcionalidade, o princípio de restrição do recurso ao tipo penal àqueles comportamentos que importem numa inequívoca lesão, ou perigo de lesão, para o bem jurídico fulcro da incriminação (princípio da ofensividade).

Nessa linha, merecedor (ou digno) de punição é todo o fato que se ajuste ao modelo de “crime como ofensa a bens jurídicos”. Decorrente do princípio da exclusiva proteção de bens jurídicos, o princípio da ofensividade ${ }^{24}$ "vincula quer o legislador quer o interprete: o legislador deve configurar os crimes como formas de ofensa a um bem jurídico, no sentido de que pode atribuir relevância penal unicamente aos fatos que comportem a lesão ou, ao menos, a exposição a perigo de um bem jurídico” ${ }^{25}$; “por sua vez, o interprete será obrigado a reconstruir os diversos tipos de crime em conformidade com o princípio de que 'não' há crime sem ofensa a bens jurídicos. Entre os múltiplos significados eventualmente compatíveis com a letra da lei, o intérprete deverá fazer uma escolha com a ajuda do critério do bem jurídico,

\footnotetext{
${ }^{23}$ FIGUEIREDO DIAS, Questões fundamentais de Direito Penal revisitadas. São Paulo: Revista dos Tribunais, 1999, p. 60.

${ }^{24}$ Sobre o princípio e a tentativa de sua fundamentação constitucional, MUSCO, Enzo. Bene giuridico e tutela dell'onore. Milano: Giuffrè, 1974, p. 116 e ss.; MARINUCCI/DOLCINI. Corso di diritto penale 1. 3. ed. Milano: Giuffrè, 2001, p. 150 e ss.; FIANDACA. Il bene giuridico, p. 49 e ss. Desenvolvidamente, MANTOVANI. Diritto Penale (PG), p. 192 e ss; PALAZZO. Valores constitucionais e direito penal, p. 80 e ss. ${ }^{25}$ Cf. MARINUCCI/DOLCINI. Corso di diritto penale..., p. 449.
} 


\section{REVI STA ELETRÔNI CA DA FACULDADE DE DI REITO DE FRANCA}

www.revista.direitofranca.br

v. 8, n.1, jul/ 2013, ISSN: 1983-4225

considerando fora do tipo incriminador os comportamentos não ofensivos ao bem”26. Coerentemente, advém como um dos mais contundentes clamores do setor doutrinário atento à importância garantista do princípio da lesividade ou ofensividade o rechaço, mais ou menos irrestrito, à figura típica dos crimes de perigo abstrato (ou quaisquer outras a esta semelhantes), nos quais a relação entre o comportamento criminoso e a criação de um perigo para o valor protegido é presumida pelo legislador ${ }^{27}$.

Exemplo extremamente contundente da proliferação de crimes de perigo abstrato, como perigo presumido, no sistema penal brasileiro, são as obsoletas contravenções penais. Tomemos, a título exemplificativo, as contravenções de "posse não justificada de instrumento de emprego usual na prática de furto” (art. 25); “violação de lugar ou objeto” (art. 26); “anuncio de meio abortivo” (art. 20); “vias de fato” (art. 21). Não há, em qualquer uma destas incriminações, a previsão de uma conduta que seja de fato ofensiva ao bem jurídico. São todos comportamentos que só ganham dignidade penal por presunção de ofensa. Em outras palavras, condutas que só se legitimam quando se acolhe um direito penal que pune a infração de um dever e confere máxima relevância ao desvalor da ação, desprezando o resultado desvalioso (por ser inexistente ou dispensável).

Não negamos legitimidade aos crimes de perigo abstrato quando o legislador adota uma técnica de tutela acertada, em consonância com o princípio da ofensividade. Contudo, existem crimes que verdadeiramente oferecem perigo ao bem jurídico (mesmo que abstrato) e aqueles que não passam de incriminações onde a tutela se antecipa de tal forma que o perigo é somente presumido e, pois, carecem de legitimidade. E estamos convictos de que a grande maioria das vigentes contravenções penais são infrações destituídas de legitimidade, ou

\footnotetext{
${ }^{26}$ Cf. MARINUCCI/DOLCINI. Constituição e escolha dos bens jurídico. (trad. José de Faria Costa), RPCC (v.2), 1994, p. 153. Com efeito, “quer seja no pano da política legislativa, quer seja no plano das normas incriminadoras, o princípio constitucional da ofensividade reveste, como é sabido, um acentuado caráter liberal, aliás coerente com suas origens históricas. A garantia dos direitos de liberdade do cidadão impede, de fato, o legislador, de antecipar o recurso à sanção penal ao momento em que se manifestam, de qualquer modo, vontade ou personalidade hostis à lei, impondo-lhe que espere a verificação de lesões tangíveis ou ameaças à integridade desta ou daquela realidade ou relação existente no mundo exterior. Se, todavia, a obra do legislador se traduzir em uma formulação com possíveis e múltiplos significados literais que abarquem, de tal sorte, também comportamentos não lesivos nem perigosos para o bem jurídico a proteger, caberá ao intérprete garantir os direitos de liberdade do cidadão, reconduzindo a repressão penal aos limites estabelecidos pelo princípio da ofensividade. O modelo de crime como ofensa a bens jurídicos - opondo-se a modelos não-liberais, como os que são próprios do moralístico direito da vontade ou da atitude interior, ou do autoritário direito penal baseado na infidelidade ao Estado ou à comunidade, ou do vago e terrorístico direito penal da personalidade perigosa assegura, portanto, à legislação penal a forma característica de um direito penal liberal "(Constituição e escolha dos bens jurídicos, pp. 153/154).

${ }^{27}$ Sobre o acertamento dogmático dos crimes de perigo abstrato e o princípios da ofensividade: D’AVILA, Fabio Roberto. Ofensividade e Crimes Omissivos Próprios, Studia Jurídica. Coimbra Editora, 2005.
} 


\section{REVI STA ELETRÔNI CA DA FACULDADE DE DI REITO DE FRANCA \\ www.revista.direitofranca.br \\ v. 8, n.1, jul/ 2013, ISSN: 1983-4225}

porque criadas para a tutela não de interesses palpáveis, mas sim “funções” do EstadoAdministração, ou porque, quando digno de tutela o bem jurídico, descrevem um comportamento inofensivo para o mesmo.

Em suma, quanto àquelas contravenções que, para além de destituídas de um autêntico bem jurídico, de forma qualquer interesse ao Estado a sua punição pelo direito, resta somente ao legislador a sua descriminalização. Da mesma forma aquelas vocacionadas para a proteção de legítimos bens jurídicos, mas que descrevem um comportamento presumidamente perigoso: é também o caso de serem descriminalizadas ou transportadas para o direito administrativo sancionador.

Contudo, se for assim, todas as outras contravenções que descreverem um comportamento que implique na ofensa ou no perigo de ofensa a um bem jurídico devem ser mantidas? Por nós a resposta será sempre negativa porque não há mais lugar no sistema punitivo brasileiro para uma categoria intermediária e cientificamente incoerente. Merecedora de pena, necessária a punição pelo direito penal, a contravenção deve ser considerada crime.

\section{DIREITO PENAL E DIREITO ADMINISTRATIVO SANCIONADOR}

Chegados neste ponto, há que sopesar - já que defendemos a descriminalização da totalidade das vigentes contravenções penais - qual a tarefa a ser desempenhada por um "novo" ramo do direto: o direito administrativo sancionador.

Já o dissemos, um dos grandes problemas que enfrenta o direito penal contemporâneo está no rompimento com mandamentos político-criminais fundamentais, peculiares ao Estado democrático de Direito. Falamos “de pequenas - para muitos, até mesmo imperceptíveis fraturas sofridas por princípios fundamentais de direito penal e constitucional em prol do bem-estar dos mais variados programas de política-criminal, o que (...) faz-se hoje especialmente preocupante no âmbito do direito penal secundário (Nebenstrafrecht)”28.

Portanto, temos por certo ser tarefa emergencial que se opere uma acertada distinção entre o ilícito penal e o administrativo sancionador. Em outras palavras, é necessário que se busque a edificação de conceitos metapositivos fortes o bastante para se poder distinguir o que é suficiente para fundamentar o ilícito de maneira geral (e, mais especificamente, o ilícito

\footnotetext{
${ }^{28}$ D`AVILA, Fabio Roberto, Direito penal e direito sancionador. Sobre a identidade do direito penal em tempos de indiferença, Revista Brasileira de Ciências Criminais, n. 60, p. 9 e ss.
} 


\section{REVI STA ELETRÔNI CA DA FACULDADE DE DI REITO DE FRANCA \\ www.revista.direitofranca.br \\ v. 8, n.1, jul/ 2013, ISSN: 1983-4225}

administrativo $^{29}$ ) daquilo que pode legitimamente, por ser digno de tutela penal, ser elevado a objeto de um tipo legal de crime. A importância de se trilhar este caminho, como já restou afirmado, está no fato de a criminalização excessiva e casuísta ter sido uma forma incoerente vislumbrada pelo legislador para satisfazer os mais variados programas de política-criminal. Transforma-se, o direito penal, em um instrumento político com vistas a satisfazer, de forma simbólica, clamores coletivos ${ }^{30}$.

Mas qual deve ser a relação a interceder entre este último e o direito administrativo sancionador (ou direito de mera ordenação social)? Quais fatores devem ser tidos em conta na distinção entre ambos os ramos do direito? Ora, em acordo ao que escreve Faria Costa, "não será difícil compreender que a problematização e as conseqüentes tentativas de dilucidação do problema do direito de mera ordenação social (...) escondem outros problemas dos quais o menor não será, por certo, a natureza do próprio direito penal”31.

3.1. Sem desprezar a evolução histórico-doutrinária, ocorrida com o nobre intuito de encontrar um critério distintivo entre o direito penal e outros ramos do direito, é a partir do primeiro grande conflito mundial que a discussão ganha maior atualidade. A crise generalizada que se abate por toda a Europa impõe ao Estado uma maior intervenção, mormente no domínio econômico. Nesse empenho, o Estado-Administrador passa a recorrer às sanções penais desmesuradamente, criando, à margem do direito penal, um sem fim número de diplomas extravagantes ao serviço dos mais diversos interesses estatais.

Foi contra essa ordem de transformações e o fenômeno da hipercriminalização dai resultado, tão bem aproveitados pelo totalitarismo nazi, que se insurgiram, no pós-guerra, alguns autores reformistas.

Distingue-se, dentre os atentos à superação deste estado de coisas, o nome de Eb. Schmidt, quem, na esteira de Goldschmidt e Wolf, defende uma distinção qualitativa entre as duas classes de ilícito. Só que a categoria (penal) das contravenções deixava de existir,

\footnotetext{
${ }^{29}$ Sobre os critérios materiais de distinção entre o Direito Penal e o direito administrativo sancionador, FARIA COSTA, José de, O perigo em direito penal, Coimbra: Coimbra Editora, 1992, p. 457 e ss. O mesmo empenho de trazer para a realidade brasileira a discussão sobre o acento distintivo entre o ilícito penal e o ilícito administrativo, afirmando ser o aspecto qualitativo e não o quantitativo que distingue o "penal” encontramos em D`AVILA, Fabio Roberto, Direito penal e direito sancionador..., p. 9 e ss. Também, apesar de chegar a conclusões distintas: FIGUEIREDO, CRIMES AMBIENTAIS. p. 113 e ss.

${ }^{30}$ Cf. ALBRECHT, Peter-Alexis, El derecho penal en la intervención de la política populista. La insustenible situación del derecho penal. Granada: Comares, 2000.

${ }^{31}$ Cf. FARIA COSTA. A importância da recorrência no pensamento jurídico. Um exemplo: a distinção entre o ilícito penal e o ilícito de mera ordenação social. IDPEE, v. 1, Coimbra: Coimbra, 1999.
} 


\section{REVI STA ELETRÔNI CA DA FACULDADE DE DI REITO DE FRANCA \\ www.revista.direitofranca.br \\ v. 8, n.1, jul/ 2013, ISSN: 1983-4225}

passando a constituir o recém chegado direito (administrativo) sancionador. Era uma resposta à inflação incriminatória do entre-guerras e uma reação aos ideais totalitários que a presidiram. Do mesmo modo, buscava delinear um núcleo de infrações que, mesmo advindas da intervenção do Estado na economia, deviam continuar a fazer parte do direito penal porque dotadas de inegável relevo ético.

Schmidt distingue crime e contra-ordenação com vistas ao diferente conteúdo material que comporta cada um deles: se o crime constitui sempre uma lesão (ou perigo de lesão) a um bem jurídico individual ou coletivo claramente individualizado, as contra-ordenações, contrariamente, não ofendem senão aos interesses da Administração, os quais que se resumem a objetivar um funcionamento sem obstáculos da máquina administrativa ${ }^{32}$. Paralelamente a esse critério de distinção, Schmidt acresce um outro "que releva da diferente atitude do agente e se relaciona com a diferente atitude ética dos valores em causa”33. Para além de tudo, há um outro ponto distintivo da doutrina de Schmidt que merece ainda ser sublinhado. É que, mesmo remetendo uma plêiade de condutas de questionável dignidade penal para dentro do direito administrativo sancionador, não se opunha à elevação à categoria de bens jurídicos de certos valores coletivos ligados aos direitos sociais e à ordenação econômica ${ }^{34}$.

No plano legislativo, a primeira expressão deste ideário viu a luz do dia, logo após a segunda guerra mundial, em 1949, com a Gesetz zur Vereinfachung des Wirtachaftsstrafrechts, diploma que já antecipa a oposição entre crimes e contra-ordenações. Posteriormente, destaca-se a Gesetz über Ordnungswidrigkeiten (de 1952), primeira Lei Quadro do direito de mera ordenação social. Dentre os avanços mais significativos do movimento de reforma da legislação vigente, desencadeado a partir de então, vale mencionar a reforma penal da R.F.A. entrada em vigor no ano de 1975. Reforma que teve o mérito de extirpar de todo a categoria das contravenções; algumas delas tendo "sido convertidas em autênticos crimes, outras em contra-ordenações, sem olvidar aquelas que foram, pura e simplesmente, eliminadas da ordem jurídica” ${ }^{35}$.

Por conseqüência, como sublinha TIEDMANN, a "descriminalização de extensas zonas da vida social fez com que no curto espaço de pouco mais de quinze anos, o direito das

\footnotetext{
, p. 142 - o itálico é nosso.

${ }^{32}$ Cf. COSTA ANDRADE, Manuel da, Contributo para o conceito de contra-ordenação (A experiência alemã). Coimbra: RDE, Anos VI/VII (1980/1981)., p. 94.

${ }^{33}$ Cf. COSTA ANDRADE. Contributo para o conceito de contra-ordenação, p. 94/5.

${ }^{34}$ Cf. COSTA ANDRADE. Contributo para o conceito de contra-ordenação, p. 95.

35 Para uma abordagem desenvolvida, que intenta cuidar do tema das contra-ordenações no contexto do movimento da descriminalização, FIGUEIREDO DIAS. Descriminalização, passim.
} 


\section{REVI STA ELETRÔNI CA DA FACULDADE DE DI REITO DE FRANCA \\ www.revista.direitofranca.br \\ v. 8, n.1, jul/ 2013, ISSN: 1983-4225}

contra-ordenações (direito administrativo sancionador) se tivesse convertido num reservatório de recolha (Sammelbecken) de infrações de proveniência muito díspar. Ao lado dos casos originários de autênticas infrações administrativas (.v. g. violação de deveres de informação, registro, contabilidade, preenchimento de formulários, etc.) apareceu - por força da conversão de numerosas contravenções em contra-ordenações - em especial, a extensa área da pequena criminalidade. Nem faltam, no mais recente direito das contra-ordenações, os delitos de perigo abstrato orientados para a tutela de bens jurídicos supra-individuais”36.

3.2. Tendo em conta esta disparidade e heterogeneidade entre as condutas condensadas sob a rubrica das contra-ordenações, a doutrina tem encontrado grandes dificuldades em alçar um critério de distinção válido e apto a abarcar todo o plurívoco catálogo atual de infrações. É, de resto, com base nessa disparidade, que um crescente número de autores vêm renunciando explicitamente a um critério material (e qualitativo) ${ }^{37}$. Desta forma, "foi se consolidando como doutrina amplamente dominante a tese da diferenciação meramente quantitativa entre ilícito penal e ilícito administrativo, segundo a qual o característico deste último é um menor conteúdo de injusto"38.

Já os autores que continuam a apostar numa diferenciação qualitativa valem-se, para tanto, dos mesmos critérios adiantados por Schmidt: o de que só autênticos crimes lesam ou expõem a perigo bens jurídicos; e o de que, enquanto o ilícito administrativo é eticamente neutro, o ilícito criminal, por seu turno, não se esgotando em uma mera desobediência eticamente indiferente, assume um inegável relevo ético-jurídico, em conta ou o desvalor ético-social da conduta ${ }^{39}$ ou a ofensividade desta para o bem jurídico ${ }^{40}$.

Porém, são muitas as críticas que se têm levantado contra as distinções puramente qualitativas: de um lado, resulta insuficiente a recorrência à noção de bem jurídico como critério único e bastante para uma distinção material porque, como vimos, o conceito de bem jurídico - mesmo tido como crítico e transcendente ao sistema jurídico-penal positivo - não diz por si só (ou autonomamente) quais devem ser as condutas dignas de serem elevadas à

\footnotetext{
${ }^{36}$ Cf. TIEDMANN. Verwaltunggsstrafrecht und Rechtsstaat, p. 288 apud COSTA ANDRADE. Contributo para o conceito de contra-ordenação, p. 97.

${ }^{37}$ Contra as posições que se afirmam numa distinção puramente quantitativa, e enfatizando que, neste horizonte discursivo, “a dignidade penal, sustentada pela valoração ético-social, surge como pedra angular de distinção”, encontramos D’AVILA. Fabio Roberto, Direito penal e direito sancionador..., pg. 9 e ss.

${ }^{38}$ Cf. SILVA SÁNCHEZ. Expansion, p. 124.

${ }^{39}$ Cf. FIGUEIREDO DIAS. Questões Fundamentais, p. 176.

${ }^{40}$ Cf. entre outros, D’AVILA. Fabio Roberto, Direito penal e direito sancionador ..., pg. 9 e ss.
} 


\section{REVI STA ELETRÔNI CA DA FACULDADE DE DI REITO DE FRANCA}

www.revista.direitofranca.br

v. 8, n.1, jul/ 2013, ISSN: 1983-4225

categoria de crime, para além de que sobram exemplos, no direito de mera ordenação social, de condutas que atentam contra verdadeiros bens jurídicos ${ }^{41}$; de outro lado, muitos se pronunciam pela inviabilidade das teses que se querem sustentar com base na neutralidade ética do ilícito administrativo sancionador ${ }^{42}$.

Não se vê, pela via oposta, coerência naqueles que, no furor de reduzir a complexidade e multiplicidade dos "motivos" que estão na base do direito administrativo sancionador, apelam para um critério que releva apenas o grau da ofensa. Assim JESCHECK, para quem “o que no fundo está em causa nas contra-ordenações é apenas isto: destacar, dentre o somatório das infrações socialmente intoleráveis, através de uma decisão positiva e discricionária do legislador, aquelas que, pela menor relevância do bem jurídico ou pelo caráter puramente abstrato do perigo, revelam menor dignidade penal mas não podem ser, pura e simplesmente, remetidas para o direito civil” ${ }^{, 43}$.

Não cremos, contudo, que uma tal distinção possa responder satisfatoriamente à diversidade fenomenológica que representa a categoria das contra-ordenações. Isso por dois motivos essenciais: primeiramente, porque resulta falacioso qualquer critério de distinção que pretenda reconduzir todos os ilícitos administrativos de caráter sancionador a infrações criminais de menor potencial ofensivo e também porque tal maneira de proceder acaba por redundar nos mesmos problemas dos critérios puramente qualitativos.

Pensamos, pois, como Costa Andrade, que uma distinção válida entre os dois domínios só se consegue à custa de uma inversão metodológica. Em vez de se querer reduzir esse ramo do direito a qualquer dos fundamentos teóricos e doutrinais que serviram à sua afirmação, a saída está em "procurar a sua redução eidética como experiência jurídica claramente referenciada, pondo entre parênteses as suas raízes históricas e doutrinais. Quando tal se fizer, não será difícil identificar um conjunto significativo de notas capazes de extremar o direito das contra-ordenações do ordenamento penal" ${ }^{44}$.

\footnotetext{
${ }^{41}$ Talvez ainda mais impressivo seja o pensamento de Roxin, quem afirma que "também as contra-ordenações lesionam bens jurídicos, posto que causam dano ao indivíduo (...) ou são prejudiciais ao o bem comum (e com isto mediatamente também para o cidadão)" (cf. Roxin, Claus, Derecho Penal - Parte General - tomo I - (trad. Diego-Manuel Luzón Peña, Miguel Diaz). Madrid: Civitas, 2000, § 2 nm. 14).

${ }_{42}$ Ressaltando a deficiência deste critério, escreve JESCHECK: "não é de forma alguma possível considerar as contra-ordenações ético-socialmente indiferentes. O Estado só pode cominar sanções repressivas para uma conduta que, segundo as concepções fundamentais da comunidade jurídica, é eticamente reprovável e suscita, por isso, censura” (cf. JESCHECK. Das deutsche Wirtsstrafrachts, p. 461 apud COSTA ANDRADE. Contributo para o conceito de contra-ordenação, p. 99).

${ }^{43}$ Cf. JESCHECK. Das deutsche Wirtsstrafrachts, p. 461 apud COSTA ANDRADE. Contributo para o conceito de contra-ordenação, nota 106.

${ }^{44}$ Cf. COSTA ANDRADE. Contributo para o conceito de contra-ordenação, p. 104.
} 


\section{REVI STA ELETRÔNI CA DA FACULDADE DE DI REITO DE FRANCA}

www.revista.direitofranca.br

v. 8, n.1, jull/ 2013, ISSN: 1983-4225

Procedimento esse que deve passar, quanto a nós, essencialmente pelos critérios que orientaram o legislador penal, nomeadamente os princípios materiais, muitos deles de refração constitucional. Assim, as categorias político-criminais da dignidade penal e da carência de tutela penal, cujo conteúdo e suporte político-criminal não se pode recorrer como um critério absolutamente eficaz, ao menos oferecem um ponto de apoio seguro a uma distinção que, não abdicando dos referentes empíricos e da experiência prático-legislativa, ressalta a importância do elemento material (e, por isso, qualitativo) ${ }^{45}$. E deve ser assim porque pensamos, alicerçados em Faria Costa, que “a problemática do direito de mera ordenação social reconduz sempre a uma reflexão acerca do direito penal (...)" ${ }^{\text {46 }}$.

A dignidade penal introduz, no debate respeitante à concepção material de crime, “considerações acerca da importância do bem e da gravidade intrínseca dos ataques ao mesmo" "47. Considerações que têm por meta, de uma outra perspectiva, servir de “contrapontos valorativos” político-criminalmente vinculantes àquelas outras considerações de cunho utilitarista que também são parte do telos do sistema e, portanto, influenciam-no muitas vezes num sentido expansivo e desatento aos valores nuclearmente determinantes do direito, como sistema axiológico. De sorte que, no juízo de dignidade (merecimento) de pena prevalece um momento axiológico (wertmoment) em que são levados em conta quais valores devem ser considerados essenciais para uma existência pacífica e responsável em comunidade e as formas de ataque mais gravosas para os mesmos. E isso, digamos mais uma vez, com o empenho de oferecer um padrão crítico tanto para o legislador quanto para o intérprete e de, assim, servir de barreira garantista contra tendências intervencionistas empreendidas em nome de um "exasperado pragmatismo eficientista”48.

\footnotetext{
${ }^{45}$ À mesma conclusão parece chegar Fábio Roberto D’Avila, a respeito da dignidade penal, quando afirma que "a liberdade, enquanto valor constitucional fundamental, somente pode ser restringida quando o seu exercício implicar a ofensa a outro bem em harmonia com a ordem axiológico-constitucional" (pg. 26). E segue: "a exigência de ofensividade é uma imposição constitucional de legitimidade" e, sendo assim, "dois níveis de valoração se fazem necessários para a verificação e aceitação de um ilícito-típico em âmbito criminal. Um primeiro nível, no qual será verificada a existência de um bem jurídico-penal...E um segundo nível, no qual se irá verificar a existência de ofensividade.... Critérios que, ao nosso sentir, muito têm a nos dizer sobre a diferenciação entre os ilícitos penal e o administrativo" (Cf. D’AVILA., Fabio Roberto. Direito penal e direito sancionador..., p. 9 e ss.)

${ }^{46}$ Cf. FARIA COSTA. A importância da recorrência no pensamento jurídico, p. 142.

${ }^{47}$ Cf. SILVA SÁNCHEZ. Aproximación al derecho penal contemporâneo. Barcelona: Bosch, 1992, p. 277. No dizer de Maria Ferreira da Cunha, "a dignidade de tutela se preocupa com quais os valores essenciais para uma dada comunidade e quais as condutas que afectam de forma particularmente grave" (cf. CUNHA, Maria da Conceição Ferreira. Constituição e Crime: uma perspectiva da criminalização e descriminalização. Porto: UCP, 1995).

${ }^{48}$ Cf. MOCCIA. De la tutela de bienes a la tutela de funciones: entre ilusiones postmodernas y reflujos iliberales in SILVA SÁNCHEZ, Política criminal y nuevo derecho penal: Libro homenaje a Claus Roxin, Barcelona, 1997, p. 115.
} 


\section{REVI STA ELETRÔNI CA DA FACULDADE DE DI REITO DE FRANCA \\ www.revista.direitofranca.br \\ v. 8, n.1, jul/ 2013, ISSN: 1983-4225}

No entanto, parece ser já consensual a convicção de que o juízo de dignidade penal, sendo indispensável, não é condição suficiente para sabermos sobre a legitimidade de uma incriminação: para além da legitimação negativa de toda a intervenção penal (mediatizada pela noção de dignidade penal), há de se acrescer um juízo positivo, que só considera legítimo o recurso ao tipo penal nos casos de comprovada necessidade (carência) de tutela. Assim, em sintonia com a linha seguida e defendida por HASSEMER, afirma-se que "uma conduta que ameaça um bem jurídico é condição necessária, mas não suficiente, para se criminalizar essa conduta" 49 .

Diferentemente do que ocorre no juízo de merecimento de pena, na categoria da carência de tutela penal prepondera uma razão funcional (Zweckrationalitat), encabeçada pelos princípios da necessidade e idoneidade (ou adequação) da intervenção penal (intervenção mínima). O primeiro deles corresponde ao mandamento de subsidiariedade e ultima ratio do direito penal: “a violação de um bem jurídico - leciona FIGUEIREDO DIAS - não basta por si para desencadear a intervenção, antes se requerendo que esta seja absolutamente indispensável à livre realização de cada um na comunidade” ${ }^{50}$; em conclusão, agora com Faria Costa, o que importa aqui é "ver se não haverá outros ramos do direito que cumpram satisfatoriamente, face às exigências de política legislativa, aquela finalidade precípua de proteção" ${ }^{51}$. Já o segundo princípio é expressão da exigência de que só se recorra ao "penal” quando a criminalização e conseqüente imposição de pena a determinado comportamento seja idônea, adequada e eficaz para cumprir, de uma forma que não implique em custos desmedidos, com sua função precípua de tutela de bens jurídico-penais.

Fica, assim, patente que essa categoria tem seu conteúdo ditado pelos dados oriundos das investigações criminológicas ${ }^{52}$, o que comprova a afirmação anterior, segundo a qual prevalece, aqui, uma lógica "voltada para a fronteira do out-put, característica dos programas finais" ${ }^{53}$.

\footnotetext{
${ }^{49}$ Cf. HASSEMER. Teoria personal del bien jurídico..., p. 278.

${ }^{50}$ Cf. FIGUEIREDO DIAS. Questões Fundamentais..., p. 78.

${ }^{51}$ Cf. FARIA COSTA. O Perigo..., 303.

52 Cf. FIGUEIREDO DIAS/COSTA ANDRADE. Criminologia: O homem delinquente e a sociedade criminógena. Coimbra: Coimbra, 1992, p. 407 e ss. Com efeito - acentuam estes últimos autores -, "todas as respostas dadas em sede de carência - e eficácia de tutela implicam uma representação da realidade, sc., da conduta a criminalizar/descriminalizar, das suas manifestações típicas, do enquadramento ambiental e interactivo, do grau de danosidade social, bem como um juízo prognóstico sobre as possibilidades e alternativas de controlo social. Daí que o conteúdo desta categoria seja, como Sax acentua, fundamentalmente criminológico" (Criminologia, p. 408).

53 Cf. COSTA ANDRADE. A “dignidade penal" e a "carência de tutela penal” como referências de uma doutrina teleológico-racional do crime, RPCC 2, 1992., p. 187. Sem descurar, todavia, que a "indispensável
} 


\section{REVI STA ELETRÔNI CA DA FACULDADE DE DI REITO DE FRANCA \\ www.revista.direitofranca.br \\ v. 8, n.1, jul/ 2013, ISSN: 1983-4225}

Por sobre tudo, é a conjunção de ambas as categorias político-criminais acima descritas que empresta sentido e conteúdo ao movimento da não-intervenção moderada ${ }^{54}$, mormente à sua vertente da descriminalização. Ora, quando se estabelece que uma determinada conduta humana deve ser descriminalizada, fato é que isso ocorrerá sempre nos casos de não estarmos diante de um comportamento que lese ou exponha a perigo bens jurídico-penais claramente individualizados (dignidade penal); ou, quando, mesmo havendo uma ofensa a um bem jurídico-penal, esta possa ser razoavelmente punida por meios extrapenais de política social (carência de tutela penal) ${ }^{55}$.

Eis, em breves linhas os dois critérios fundamentais que circunscrevem e legitimam a intervenção do direito penal. Obviamente, pela via dessa conceituação não se deslinda a problemática concernente à distinção entre direito penal e direito administrativo sancionador. Principalmente porque o direito administrativo sancionador comporta condutas dignas e merecedoras de pena e também pelo fato de ser o direito administrativo sancionador um ramo do direito sancionatório dotado de particularidades dogmáticas que fogem do universo jurídico-criminal. Cumpre salientar, contudo, que nenhuma destas dificuldades de categorização importa no rechaço às vetustas contravenções penais. A dificuldade em se encontrar um critério polivalente para se definir o que distingue o direito penal do administrativo, não implica em considerar legítima uma categoria intermediária a ambos.

\section{FALÊNCIA POLÍTICO-CRIMINAL DAS CONTRAVENÇÕES PENAIS}

4.1. Já o dissemos, existem várias contravenções que não se dirigem à tutela de bens jurídico-penais. São, portanto, indignas de tutela penal e devem ser descriminalizadas. Neste quadro se inserem, $v . g$., as contravenções que tem como objeto de proteção conceitos nebulosos, vagos e ilegítimos (a paz pública, a polícia de costumes, a organização do trabalho, etc.). Não há aqui um bem jurídico-penal coletivo a ser protegido e sim, quando muito, um

racionalidade funcional está inteiramente 'colonizada' pela densidade axiológica própria da wertrationalität" (RPCC 2 (1992), p. 182).

${ }^{54}$ Sobre esta proposição, em suas diretrizes fundamentais, FIGUEIREDO DIAS. Direito Penal Português (as conseqüências jurídicas do crime), p. 65 e ss. Do mesmo Autor, Questões Fundamentais, p. 81.

${ }^{55}$ Daí a afirmação de COSTA ANDRADE de que dignidade e carência de tutela penal "mediatizam e tornam operativos os princípios constitucionais que demarcam o horizonte da criminalização: imanência sistêmicosocial, proporcionalidade, caráter fragmentário e subsidiariedade" (cf. COSTA ANDRADE. RPCC 2 (1992), p. 187). 


\section{REVI STA ELETRÔNI CA DA FACULDADE DE DI REITO DE FRANCA \\ www.revista.direitofranca.br \\ v. 8, n.1, jul/ 2013, ISSN: 1983-4225}

bem jurídico que se confunde com funções administrativas de controle da vida social. Desta forma, se, por exemplo, a contravenção de "perturbação do trabalho e do sossego alheios” (art. 42) não protege um bem jurídico-penal, não será desarrazoado dizer que há aqui um interesse do Estado-Administração digno de tutela pelo direito administrativo sancionador. No mesmo caso podemos incluir a contravenção que, pretensamente voltada à proteção da “polícia de costumes”, controla a venda de bebidas alcoólicas (art. 63): não se trata, in casu, de um bem jurídico-penal como já se demonstrou, mas de um interesse legítimo da Administração em restringir a mercancia de bebidas alcoólicas; interesse que, se não legitima a intervenção do direito penal, o mesmo não se pode dizer do direito administrativo sancionador.

Portanto, neste primeiro conjunto, é a dignidade penal (merecimento de pena) o conceito que serve, e basta, para que se conclua a favor da descriminalização das contravenções penais. Caberá ao legislador, num momento posterior, eleger aquelas condutas que, conquanto contrarias a funções de ordenação próprias do Estado-Administrador, devem ser punidas por uma sanção administrativa.

4.2. Por outro lado, há aquelas contravenções que tem como objetos de proteção interesses individuais, como a vida ou a integridade física (pessoa) e o patrimônio, ou autênticos bens jurídicos supra-individuais, como a incolumidade pública. Aqui não se questiona a legitimidade do bem jurídico em si mas sim a (in)ofensividade da conduta típica. A constatação da existência de um bem jurídico-penal não basta para que se considere o ilícito-típico digno de tutela penal: se a presença de um bem jurídico-penal é o primeiro nível de valoração para que seja a incriminação digna de tutela pelo direito penal, resta uma segunda valoração, que busca a compatibilidade do ilícito-típico com o princípio da ofensividade ${ }^{56}$.

Pensemos, a título exemplificativo, na contravenção, referente à pessoa, de "fabrico, comércio ou detenção de armas ou munição” (art. 18), ou, referente ao patrimônio, nas de “instrumento de emprego usual na prática de furto” (art. 24), “posse não justificada de instrumento de emprego usual na prática de furto” (art. 25), “violação de lugar ou objeto” (art. 26). Ora, não se questionando sobre a existência do bem jurídico que, segundo o legislador, confere legitimidade ao ilícito-típico, é, por sua vez, extremamente duvidosa a capacidade de

\footnotetext{
${ }^{56}$ Cf. D’AVILA., Fabio Roberto. Direito penal e direito sancionador, p. 9 e ss.
} 


\section{REVI STA ELETRÔNI CA DA FACULDADE DE DI REITO DE FRANCA \\ www.revista.direitofranca.br \\ v. 8, n.1, jul/ 2013, ISSN: 1983-4225}

a conduta descrita no tipo expô-lo a perigo, mesmo que abstrato. E de nada adianta um bem jurídico digno de tutela penal se o ilícito-típico que o agasalha descreve uma ação ou omissão de tal forma antecipada que não chega a tangenciá-lo. Exemplo do mesmo modelo são também as contravenções, referentes à incolumidade pública, de "violação de lugar ou objeto" (art. 26), “desabamento de construção (art. 29), “perigo de desabamento” (art. 30).

Ora, toda vez que uma conduta definida em um tipo legal de crime for contrária ao princípio da ofensividade, tal como nos exemplos acima estampados, devem ser descriminalizadas por serem indignas de tutela penal. Os ilícitos administrativos neste caso serão compostos por infrações socialmente intoleráveis, pela via de uma decisão positiva e discricionária do legislador, dentre aquelas que, pela menor relevância do bem jurídico ou pelo caráter puramente abstrato do perigo, revelam menor dignidade penal mas não podem ser, pura e simplesmente, descriminalizadas ou remetidas ao direito civil. Portanto, nestas contra-ordenações a diferença diante do direito penal será sempre quantitativa.

4.3. Poder-se-ia pensar que, não se tratando de contravenções destituídas de um verdadeiro bem jurídico ou inofensivas para bens jurídicos dotados de dignidade penal, tal como nos exemplos acima descortinados, as restantes seriam legítimas. Mas, tratando-se de uma contravenção que descreve uma conduta merecedora de pena, terá o legislador duas opções: converte-la em autêntico crime ou remetê-la para o direito administrativo sancionador. O princípio que agora opera de parâmetro político-criminal é a carência de tutela penal (necessidade de pena).

Apesar da precária e obsoleta técnica de tipificação há, sem sombra de dúvida, contravenções merecedoras de pena; infrações que descrevem uma conduta que é concretamente ofensiva a um determinado bem jurídico-penal (mesmo que coletivo). Pensamos que aqui se incluem as contravenções, referentes à incolumidade pública, de “disparo de arma de fogo” (art. 28), “falta de habilitação para dirigir veículo” (art. 32), “direção não licenciada de aeronave” (art. 33), “abuso na prática de aviação” (art. 35), “direção perigosa de veículo em via pública” (art. 34). Quanto a estas transgressões, prova da sua dignidade penal é o fato de terem sido, as duas primeiras, revogadas e transformadas em autênticos crimes $^{57}$ de perigo. Assim, para além de o legislador ter demonstrado,

\footnotetext{
${ }^{57}$ A contravenção de disparo de arma de fogo foi revogada pela Lei 9.437/97 e posteriormente, transformada em crime pelo art. 15 da Lei 10.826/2003. Já a contravenção do art. 32 da LCP, derrogada pelo Código de Trânsito Brasileiro (Lei 9.503/97), foi transformada também em crime quando o autor não possui habilitação para dirigir
} 


\section{REVI STA ELETRÔNI CA DA FACULDADE DE DI REITO DE FRANCA \\ www.revista.direitofranca.br \\ v. 8, n.1, jul/ 2013, ISSN: 1983-4225}

concretamente, que uma contravenção, quando digna e carente de tutela penal, deve ser transformada em autêntico crime, fica claro que para o juízo de imputação não basta o pôrem-perigo abstrato presumido, requerendo-se sempre para o preenchimento do tipo um resultado de perigo para o bem jurídico ${ }^{58}$.

Assim, no último caso estudado (contravenções merecedoras de pena), cabe ao legislador optar pela verdadeira criminalização ou pela descriminalização e transformação em ilícito administrativo. E elegerá uma ou outra medida levando em conta a necessidade de pena. Portanto, se estivermos diante de uma conduta que, para além de ofensiva a um valor dotado de referência constitucional e indispensável à sobrevivência da sociedade (bem jurídico-penal), não dispensar a intervenção do direito penal, deve haver a concreta criminalização. E quando não se dispensa a concreta intervenção do direito penal? Quando o recurso ao direito penal, com seus instrumentos próprios de atuação (penas criminais), for necessário e eficaz.

Será necessário quando não se puder socorrer de outras formas de tutela, menos atentatórias a direitos individuais que as sanções jurídico-criminais, para se obter o almejado efeito preventivo. Noutros termos, recorre-se ao direito penal quando, por exemplo, com sanções próprias do direito civil ou administrativo, não ocorre o esperado efeito de prevenção daquela espécie de comportamento.

Contudo, para além de ser necessária a pena criminal, é preciso que a mesma seja eficaz. Como não é mais defensável que seja atribuída à pena a finalidade de castigo, retribuição ou expiação, a mesma só será legítima quando capaz de atingir algum efeito preventivo. Há pois casos, demonstrados estatisticamente, em que com a pena criminal não se obtém nenhum efeito preventivo (seja ele geral ou especial). Há crimes em que a pena só é aplicada a uma ínfima parcela dos infratores e em que há, portanto, grandes cifras negras entre os ilícitos ocorridos e a efetiva punição. Nestes casos, não se recorre ao direito penal, por mais merecedora de pena que for a conduta, pois a pena criminal somente pune bodes

veículo automotor (art. 309 do CTB), remanescendo apenas a contravenção quanta à falta de habilitação para embarcação a motor em águas públicas (súmula 720 do STF).

${ }^{58}$ Quanto o crime de disparo de arma de fogo, crime de perigo abstrato, que, protegendo a incolumidade pública, pode ser considerado ofensivo ou inofensivo a partir de um juízo de probabilidade ex post ver: ZUANAZZI, Guilherme, $O$ tipo penal de disparo de arma de fogo como espécie dos delitos contra a incolumidade pública (uma antecipação da tutela penal legitimável). Dissertação de Mestrado (UNESP), 2009, no prelo. Já o crime do art. 309 do CTB, foi redigido, como pacificamente se entende, como crime de perigo concreto, sendo necessário, pois, para o juízo de tipicidade a prova da ocorrência de um resultado de perigo. 


\section{REVI STA ELETRÔNI CA DA FACULDADE DE DI REITO DE FRANCA \\ www.revista.direitofranca.br \\ v. 8, n.1, jul/ 2013, ISSN: 1983-4225}

expiatórios e não atinge nenhuma finalidade, para além de carregar um pernicioso efeito simbólico.

Portanto, havendo necessidade e merecimento de pena, deve a contravenção ser verdadeiramente criminalizada. Contudo, as infrações merecedoras de pena em que a sanção administrativa pode atuar de maneira menos ofensiva a direitos individuais e tão ou mais eficazmente que a pena criminal são o locus privilegiado para a intervenção do direito administrativo sancionador.

\section{CONCLUSÃO}

O que se espera do direito penal de hoje? A pergunta, que pode ser extremamente intricada, perderá em complexidade se a resposta se buscar pelo avesso. Não se pode esperar do direito penal que ele assuma compromissos que não lhe cabem, que fogem do seu eixo de preocupações. E este eixo, por mais figurativo ou provisório que possa parecer, não o é: cumpre ao direito penal a tarefa de proteger, de forma subsidiária, bens jurídicos fundamentais. Desta breve proposição de política criminal deriva todo um programa dotado de uma intencionalidade apta a orientar de forma acertada as escolhas do legislador. Uma intencionalidade que, pensamos, se condensa em duas grandes linhas de força: o merecimento e a necessidade de pena.

Se é assim e se a opção político-legislativa pelas contravenções penais é, por variados prismas, abominável, devemos empreender uma interpretação das vigentes contravenções penais à luz destes dois princípios legitimadores. Com uma tal interpretação, mesmo que não te todo linear e esgotante, demonstra-se a necessidade de descriminalização das vigentes contravenções penais e, quando oportuna, a sua conversão em ilícitos administrativos.

Passa a ser, o direito administrativo sancionador, um "reservatório” para onde deverão ser remetidas todas aquelas contravenções destituídas de um autêntico bem jurídico, aquelas outras inofensivas para um bem jurídico-penal e, finalmente, as que, mesmo descrevendo condutas ofensivas a bens jurídico-penais, encontram nas sanções administrativas um modelo de controle tão ou mais eficiente ${ }^{59}$ que o jurídico-penal.

59 Em resumo, nenhuma contravenção penal é legítima. Seja porque não ofende ou expõe a perigo, verdadeiramente, um bem jurídico-penal, seja porque a imposição das suas sanções específicas (prisão simples e multa) será sempre ineficaz. A ineficácia preventiva das contravenções penais facilmente se comprova se partirmos de uma abordagem penológica. As penas cominadas pelas contravenções penais raramente são aplicadas concretamente, uma vez que - para além das elevadas cifras negras oriundas da discricionariedade da 


\section{REVI STA ELETRÔNI CA DA FACULDADE DE DI REITO DE FRANCA \\ www.revista.direitofranca.br \\ v. 8, n.1, jul/ 2013, ISSN: 1983-4225}

Como se viu, cumpre, o direito administrativo sancionador, um papel fundamental no discurso descriminalizador. Papel que, a um tempo, aponta de forma absoluta para a incoerência político-criminal das contravenções penais e oferece um instrumento de apoio para o chamado direito penal secundário. Assunto extremamente atual e carente de contribuições doutrinárias, tão mais urgentes quanto mais se nota, na realidade legislativa brasileira, a edição de crimes desmesuradamente na parte extra codicem, sem importar-se o legislador com a efetiva ofensividade dos tipos legais (inflação legislativa) ou com sua eficácia preventiva.

\section{REFERÊNCIAS BIBLIOGRÁFICAS}

ALBRECHT, Peter-Alexis, El derecho penal en la intervención de la política populista. La insustenible situación del derecho penal. Granada: Comares, 2000

ANDRADE, Manuel da Costa. Contributo para o conceito de contra-ordenação (A experiência alemã). Coimbra: RDE, Anos VI/VII (1980/1981).

A “dignidade penal" e a "carência de tutela penal" como referências de uma doutrina teleológico-racional do crime, RPCC 2, 1992.

ANGIONI, Francesco. Contenuto i funzioni del concetto di bene giuridico. Milano: Giufré, 1983.

BARATTA, Alessandro. Integración-prevención: una “nueva” fundamentación de la pena dentro de la teoría sistémica, Doctrina Penal, nº 29, 1985.

Funções instrumentais e simbólicas do direito penal: Lineamentos de uma teoria do bem jurídico. RBCC, nº 5, 1994.

, Criminologia critica y política penal alternativa, RIDP: 1978

autoridade policial em levar a infração ao conhecimento do poder judiciário -, incidindo o rito definido pela Lei 9.099/95, sobrevirá sempre um daqueles institutos despenalizadores ali dispostos. Ou, por outro lado, aplicada a pena de prisão simples, será substituída por pena restritiva de direitos, segundo os critérios do art. 43 e ss. do Código Penal. Nos raríssimos casos de imposição de pena de prisão simples e não de multa, deparamo-nos com a absoluta inexistência de estabelecimentos adequados para satisfazer a ingenuidade do legislador que, no art. $6^{\circ}$ da Lei de Contravenções Penais, estabeleceu um impraticável regime de cumprimento de pena para o contraventor.

Portanto, aquele que praticar uma contravenção penal, quando o fato chegar ao conhecimento da autoridade judiciária, sofrerá sempre uma sanção não privativa de liberdade. Sendo político-criminalmente coerente a aplicação de sanções alternativas à prisão nos crimes de pequeno potencial ofensivo, o que se questiona é o fato de a grande maioria das contravenções não serem infrações nem de pequeno potencial ofensivo, porquanto inofensivas. O sistema de penas se dispõe, desta forma, às avessas. A grande maioria das contravenções dignas de pena não são punidas ou punidas desmesuradamente por um sistema sancionatório aleatório. O restante das contravenções, não dotadas de dignidade penal, serve como objeto de desvirtuamento do sistema penal alternativo. 


\section{REVI STA ELETRÔNI CA DA FACULDADE DE DI REITO DE FRANCA \\ www.revista.direitofranca.br \\ v. 8, n.1, jul/ 2013, ISSN: 1983-4225}

BECCARIA, Cesare, Dos Delitos e das Penas, tradução: José de FARIA COSTA, ED: Fundação Calouste Gulbenkian, Lisboa:1998.

BECK, Ulrich. Risk Society - towards a new modernity. London/ Thousand Oaks/ New Delhi: Sage Publications, 1992.

CATENACCI, Mauro. La tutela penale dell'ambiente: Contributo all'analisi delle norme penali a struttura “sanzionatória”. Milano: Cedam, 1996.

COSTA, José de Faria. A importância da recorrência no pensamento jurídico. Um exemplo: a distinção entre o ilícito penal e o ilícito de mera ordenação social. IDPEE, v. 1, Coimbra: Coimbra, 1999.

. O perigo em direito penal: contributo para a sua fundamentação e compreensão dogmáticas. Coimbra: Coimbra, 2000.

CUNHA, Maria da Conceição Ferreira. Constituição e Crime:uma perspectiva da criminalização e descriminalização. Porto: UCP, 1995.

D’AVILA, Fabio Roberto, Ofensividade e Crimes Omissivos Próprios, Studia Juridica, Coimbra Editora, 2005.

. Direito penal e direito sancionador. Sobre a identidade do direito penal em tempos de indiferença, Revista Brasileira de Ciências Criminais, n. 60.

DIAS, Augusto Silva. Protecção jurídico-penal dos interesses dos consumidores. 2. ed. Policopiada das "Lições" aos Cursos de Pós-graduação em Direito do Consumo e em Direito Penal Econômico e Europeu, FDUC, 2000.

DIAS, Jorge de Figueiredo. Direito penal e Estado de Direito Material: sobre o método, a construção e o sentido da doutrina geral do crime. RDP, fasc. 31. Rio de Janeiro, 1981.

. Os novos rumos da política criminal e o direito penal português do futuro. Lisboa: ROA (1983).

Questões fundamentais de Direito Penal revisitadas. São Paulo: Revista dos Tribunais, 1999.

, Direito Penal Português (as conseqüencias jurídicas do crime), Ed: Notícias, Lisboa: 1993

. O direito penal entre a "sociedade industrial" e a "sociedade do risco" in Estudos em Homenagem ao Doutor Rogério Soares (a publicar).

DIAS, Jorge de Figueiredo/ ANDRADE, Manuel da Costa. Criminologia: O homem delinquente e a sociedade criminógena. Coimbra: Coimbra, 1992.

FIGUEIREDO, Guilherme Gouvêa de, Doutrinas Funcionalistas em Direito Penal. Revista de Estudos Criminais, Porto Alegre: Notadez, v. 30, p. 25-54, 2008.

CRIMES AMBIENTAIS À LUZ DO CONCEITO DE BEM JURÍDICO-PENAL (des)criminalização, redação típica e (in)ofensividade,IBCCRIM, São Paulo: 2008. 


\section{REVI STA ELETRÔNI CA DA FACULDADE DE DI REITO DE FRANCA \\ www.revista.direitofranca.br \\ v. 8, n.1, jul/ 2013, ISSN: 1983-4225}

FERNANDES, Fernando Andrade. O processo penal como instrumento de política criminal. Coimbra: Almedida, 2001.

FERNANDES, Paulo Silva, Globalização, "sociedade de risco" e o Futuro do Direito Penal. Coimbra: Almedina, 2001.

FIANDACA, Giovanni. Il bene giuridico come problema teorico e come criterio di politica criminale in RIDPP., 1982.

. La tipizzazione del pericolo, Dei delitti e delle pene, 1982

FIORE, Carlo, Il princípio di offensività in Ind. Pen, 1994, p. 278 ss.

FRISCH, Wolfgang. La imputación objetiva: estado de la cuestión in AA. VV. Sobre el estado de la teoría del delito. Madrid: Civitas, 2000.

. Bien jurídico, derecho, estrutura del delito e imputación em el contexto de la legitimación de la pena estatal, in: HEFENDEHL, Roland, La teoria del bien juídico, Marcial Pons, Barcelona: 2007, p. 309 e ss.

GRECO, Luis, "Princípio da ofensividade e crimes perigo abstrato - Uma introdução ao debate sobre o bem jurídico e as estruturas do delito, Revista Brasileira de Ciências Criminais, vol. 49, pg. 93 e ss..

GUISINO, Manfredi Parodi. I reati di pericolo tra dogmatica e politica criminale, Milano: Giuffrè, 1990.

HASSEMER, Winfried. Il bene giuridico nel rapporto di tensione tra constituzione e diritto naturale, Dei Delitti e Delle Pene, n¹, 1984, p. 104 ss.

. Lineamentos de una teoría personal del bien jurídico, Doctrina Penal, año 12, n. ${ }^{\circ} 45$ a 48, Buenos Aires, 1989, p. 275 ss.

. Derecho Penal Simbólico y Protección de Bienes Jurídicos, Pena y Estado. n.ํ1, Barcelona, 1991, p. 23 ss.

, Pueden haber delitos que no afecten a um bien jurídico penal? In: HEFENDEHL, Roland, La teoria del bien juídico, Marcial Pons, Barcelona: 2007

HEFENDEHL, Roland, El bien jurídico como eje material de la norma penal, in: HEFENDEHL, Roland, La teoria del bien juídico, Marcial Pons, Barcelona: 2007

MARINUCCI, Giorgio/DOLCINI, Corso di diritto penale 1. 3. ed. Milano: Giuffrè, 2001.

MENDOZA BUERGO, Blanca. El derecho penal en la sociedad del riesgo. Madrid: Civitas, 2001. . Límites dogmáticos y político-criminales a los delitos de peligro abstracto,

Estudios de derecho penal. Granada: Comares, 2001.

MOCCIA, Sergio. De la tutela de bienes a la tutela de funciones: entre ilusiones postmodernas y reflujos iliberales in Silva Sánchez, Política criminal y nuevo derecho pena: Libro homenaje a Claus Roxin, Barcelona, 1997, p. 113 ss. 


\section{REVI STA ELETRÔNI CA DA FACULDADE DE DI REITO DE FRANCA \\ www.revista.direitofranca.br \\ v. 8, n.1, jul/ 2013, ISSN: 1983-4225}

MÜLLER-TUCKFELD, J-C. Abolición del derecho penal del medio ambiente in La insostenible situación del Derecho penal. Área de Derecho Penal de la Universidad Pompeu Fabra, Granada: 2000, p. 507 ss.

MUSCO, Enzo. Bene giuridico e tutela dell'onore. Milano: Giuffrè, 1974.

PADOVANI, Tullio. La problematica del bene giuridico e la scelta delle sanzioni in Dei Delitti e delle Pene. 1984, p. 116 ss.

PAGLIARO, Antonio. Principi di diritto penale. Parte generale, Milano: Giuffrè, 1993.

PALAZZO, Francesco Carlo. Valores constitucionais e direito penal: Um estudo Comparado. Porto Alegre: Sérgio Antônio Fabris, 1989

PATRONO, Paolo. Inquinamento industriale e tutela penale dell ambiente, Padova: CEDAM, 1980. I reati in materia di ambiente in Riv. trim. Dir. Pen. Econ., 2000, p. 669 ss.

PEDRAZZI, Cesare. Profili penalistici di tutela dell'ambiente in Ind. Pen., 1991, p. 617 ss.

ROXIN, Claus. Política criminal y sistema de derecho penal. Elementos del delito en base a la política criminal (trad. J. Bustos y H. Hormazábal), Barcelona, 1992.

. Derecho Penal - Parte General - tomo I - (trad. Diego-Manuel Luzón Peña, Miguel Diaz). Madrid: Civitas, 2000.

.La evolución de la Política criminal, el Derecho Penal y el processo penal. Valencia: Tirant lo Blanch, 2000.

RUDOLPHI, Hans Joachim. Los diferentes aspectos del concepto de bien jurídico. Nuevo Pensamiento Penal, año 4, nº 5 a 8, 1975, p. 329 ss.

SALES, Sheila Jorge Selim de. Princípio da efetividade no direito penal e a importância de um conceito garantista do bem jurídico penal. Revista dos Tribunais, São Paulo : RT, junho/2006, v. 848, p. 416-437, 2006.

SILVA SÁNCHEZ, Jesús Maria. Aproximación al derecho penal contemporâneo. Barcelona: Bosch, 1992.

Política criminal y técnica legislativa en materia de delitos contra el medio ambiente in Cuadernos de Doctrina y Jurisprudencia Penal. Buenos Aires, 1997. [=Consideraciones teóricas sobre la reforma de los delitos contra el medio ambiente, in: ADPCP, 1997, p. 151 ss.].

. Delitos contra el medio ambiente. Valencia: Tirant lo Blanch, 1999.

La expansión del Derecho penal. Aspectos de la política criminal de las sociedades postindustriales. Madrid: Civitas, 1999.

. Política criminal en la dogmática: algunas cuestiones sobre su contenido y lImites in: La evolución de la Política criminal, el Derecho Penal y el proceso penal. Valencia: Tirant lo Blanch, 2000. 


\section{REVI STA ELETRÔNI CA DA \\ FACULDADE DE DI REITO DE FRANCA}

www.revista.direitofranca.br

v. 8, n.1, jul/ 2013, ISSN: 1983-4225

SIMÕES, Pedro Coelho, A supra-individualidade como factor de superação da razão humana, Temas de direito penal económico, COIMBRA: Coimbra editora, 2001.

SOUZA, Paulo Vinicius Sporleder. O meio ambiente (natural) como sujeito passivo dos crimes ambientas, RBCC, vol. 50

Bem Jurídico-Penal e Engenharia Genética Humana, RT, 2004

STRATENERTH, Günter, DERECHO PENAL.PARTE GENERAL (el hecho punible).Navarra: Civitas, 2005.

WOHLERS, Wolfgang/HIRSCH, Andrew Von, Teoria del bien jurídico y estructura del delicto. Sobre los critérios de uns imputación justa, in: HEFENDEHL, Roland, La teoria del bien juídico, Marcial Pons, Barcelona: 2007, p. 285 e ss.

ZUANAZZI, Guilherme, O tipo penal de disparo de arma de fogo como espécie dos delitos contra a incolumidade pública (uma antecipação da tutela penal legitimável). Dissertação de Mestrado (UNESP), 2009, prelo. 